\title{
OS NOMES E AS COISAS: (RE)DISCUTINDO A LINGUAGEM DO CRÁTILO DE PLATÃO ${ }^{1}$
}

Amanda Mikaelly Nobre de Souza ${ }^{2}$

Resumo: Este artigo apresenta uma (re)discussão de cunho teórico acerca da linguagem, especificadamente, no que tange à aplicação dos nomes em relação às coisas, trazida por Platão no Diálogo Crátilo. Para tanto, este estudo encontra-se organizado em três partes: i) Síntese do Crátilo; ii) Os nomes e as coisas: por natureza ou convenção? iii) (Re)discutindo a linguagem: do Crátilo aos diálogos atuais. Assim, intenciona-se com este artigo expor, de modo organizado, as principais ideias postas no texto platônico e, a partir disso, rediscutir a noção de linguagem. Com embasamento nas discussões de Dietzsch (2007), Oliveira (2001), Mondada e Dubois (2003) e Piqué (1996), especificadamente, o estudo realizado revela que o conhecimento em torno da linguagem é inconclusivo, não há respostas a respeito da aplicação dos nomes em relação às coisas, e dinâmico, os objetos que nomeiam as coisas são resultados de (re)construções de natureza intersubjetiva. Espera-se, com este artigo, conduzir uma compreensão esclarecedora acerca desse diálogo, que apresenta uma discussão canônica sobre o ato de nomear, de referir-se às coisas, hoje ressignificada nos estudos linguísticos, estes inevitavelmente alicerçados nas investigações de cunho filosófico.

Palavras-chave: Linguagem. Realidade. Crátilo. Atualidade.

\section{NAMES AND THINGS: (RE)DISCUSSING THE LANGUAGE OF PLATO'S CRATYLUS}

Abstract: This article presents a theoretical (re)discussion about language, specifically with regard to the application of names in relation to things, brought by Plato in the Cratylus Dialogue. To this end, this study is organized in three parts: 1) Synthesis of the Cratylus; 2) Names and things: by nature or convention? 3) (Re)discussing language: from Cratylus to current dialogues. Thus, it is intended with this article to expose, in an organized way, the main ideas put in the Platonic text and, from that, to rediscuss the notion of language. Based on the discussions of Dietzsch (2007), Oliveira (2001), Mondada and Dubois (2003) and Piqué (1996), specifically, the study reveals that knowledge about language is inconclusive, there are no answers about the application of the names in relation to things, and dynamic, the objects that name things are the result of (re)constructions of an intersubjective nature. It is hoped, with this article, to lead an enlightening understanding about this dialogue, which presents a canonical discussion about the act of naming, of referring to things, reframed today in linguistic studies, inevitably grounded in philosophical investigations.

Keywords: Language. Reality. Cratylus. Today.

1 A princípio, este texto foi apresentado como requisito obrigatório para avaliação na disciplina Filosofia da Linguagem, do Programa de Pós-Graduação em Letras (PPGL), da Universidade do Estado do Rio Grande do Norte (UERN), ministrada pelo Prof. Dr. Ivanaldo Oliveira dos Santos Filho (In memoriam), no primeiro semestre de 2019, a quem agradeço pela mediação de enriquecedoras discussões, bem como pelas contribuições trazidas a este artigo.

2 Mestranda em Letras pelo Programa de Pós Graduação em Letras (PPGL) na Universidade do Estado do Rio Grande do Norte (UERN).E-mail: amandasouza1997@outlook.com 


\section{Primeiras palavras}

O Diálogo Crátilo talvez seja uma das obras de Platão que mais causou repercussão na segunda metade do século XX (PIQUÉ, 1996), que pode ser entendida em razão da virada pragmática ou giro linguístico da filosofia contemporânea, isto é, o fato de todas as pesquisas, em geral, e questões filosóficas serem trabalhadas, inevitavelmente, através de um estudo acerca da linguagem.

Por esse viés, é válida a defesa, de acordo com Santos (2013, p. 214), da ideia de que "não podemos falar do mundo a não ser por intermédio da linguagem, pois é em seu seio que os sujeitos têm acesso ao real". Ou seja, a linguagem, em suas diversas formas, media o nosso acesso à realidade, é, na verdade, o único meio do homem representar o mundo que habita, o instrumento que mantém e legitima efetivamente as coisas dentro da realidade humana.

Concomitante a isso, é coerente dizer que a linguagem é o que nos torna humanos, o que nos diferencia das demais espécies de animais, é o que viabiliza a humanização. Partindo dessa perspectiva, e entendendo que a linguagem (re) constrói as coisas, este artigo objetiva apresentar uma (re)discussão de cunho teórico em torno da linguagem, especificadamente, no que se refere à aplicação dos nomes em relação às coisas, trazida por Platão no Diálogo Crátilo.

Considerando as inúmeras teorias e questões que o texto platônico apresenta, bem como a breve discussão que este espaço possibilita para isto, optou-se por explorar teoricamente as teses naturalismo e convencionalismo, posições que permitem estabelecer uma discussão em torno da linguagem, especificadamente acerca dos nomes e das coisas.

A respeito disso, vários teóricos e pesquisadores apresentam trabalhos que comentam o referido diálogo, sobretudo no que abrange a linguagem e a realidade. Dentre eles, para este artigo, buscou-se embasamento nas discussões teóricas de: Dietzsch (2007), Oliveira (2001), Pereira (2008), Piqué (1996) e Santos (2009; 2010; 2013). Ademais, Mondada e Dubois (2003) e Teixeira e Soares (2013), especificadamente, fundamentam a discussão em torno dos diálogos atuais acerca da linguagem.

Assim sendo, no que tange aos aspectos metodológicos, esta pesquisa é de natureza qualitativa e adota um viés exploratóriointerpretativo na discussão proposta, uma vez que delineia-se o tema estudado, com olhar voltado para um novo tipo de enfoque (PRODANOV; FREITAS, 2013), isto é, propõe-se uma (re) discussão acerca do objeto de estudo das ciências da linguagem: a própria linguagem.

Partindo desse postulado, a relevância desta pesquisa está na natureza canônica do texto platônico, o qual propõe-se discutir e, partir dele, rediscutir a noção de linguagem, que é de interesse comum a todas as disciplinas linguísticas e literárias. A partir deste argumento, defende-se a necessidade de compreender a obra Crátilo, referência aos estudos que discutem língua e realidade.

De modo a elucidar a compreensão da discussão proposta, o plano de escrita deste artigo encontra-se organizado em três seções teóricas, nas quais se: i) apresenta uma síntese do Diálogo Crátilo, que revela a não obtenção de uma resposta conclusiva quanto à aplicação dos nomes às coisas, de natureza filosófica; ii) discute a respeito das teses naturalismo e convencionalismo, que tratam da origem dos nomes que designam as coisas; e iii) reflete, a partir das discussões anteriores, acerca de como a linguagem é apreendida nos diálogos atuais. Ao final, são tecidas as considerações finais sobre o estudo realizado. 


\section{Síntese do Crátilo}

Escrito no século IV antes de Cristo, o Diálogo Crátilo é constituído de três personagens: 1) Crátilo, que apresenta uma visão naturalista da linguagem - por natureza, 2) Hermógenes, que compreende a aplicação dos nomes às coisas, segundo uma percepção convencionalista - por convenção e 3) Sócrates, ou por melhor dizer, o próprio Platão, que discute filosoficamente o problema da justeza dos nomes considerando ambas as teses, por natureza e por convenção, contrapondo-as e relacionando-as no decorrer do diálogo.

Crátilo sustenta que cada coisa tem por natureza um nome apropriado (Hermógenes, 383a), sentido correto, sendo o nome a expressão correta da respectiva coisa, por exemplo, a palavra "parede" designa com perfeição o objeto parede, fazendo todo sentido chamarmos parede de parede e não de outro nome.

Por outro lado, Hermógenes defende a tese convencionalista acerca da ação de nomear, assegurando que nenbum nome é dado por natureza a qualquer coisa, mas pela lei e o costume dos que se habituaram a chamá-la dessa maneira (Hermógenes, 384d), isto é, as coisas têm determinados nomes porque convencionou-se, por costume, chamar de tal forma. Para ele, o ato de nomear é arbitrário - a coisa tem um nome arbitrariamente -, não podendo ser justificável em razão das percepções individuais de mundo, práticas sociais, fatores culturais, aspectos externos à linguagem, e etc., como postulam os estudos atuais -, mas porque eventualmente convencionou-se ser nomeada como tal.

Já Platão, na personagem de Sócrates, discute a exatidão dos nomes considerando essas duas teses divergentes, de modo a não concordar, plenamente, com uma ou outra. Isso porque, segundo Santos (2013, p. 215),
[...] o objetivo da especulação sobre a linguagem não é demonstrar se a mesma é natural (posição de Crátilo) ou convencional (posição de Hermógenes), mas que tem uma dimensão natural, no sentido que há categorias universais e metafísicas a serem observadas, e, ao mesmo tempo, convencional, visto que a mesma está ligada à diversidade das atividades sócio-culturais do ser humano.

Assim sendo, a obra consiste, sinteticamente falando, no diálogo de Platão com Crátilo e Hermógenes a respeito de suas teses, de modo a examiná-las, por meio de questionamentos, revelando que, na verdade, a origem dos nomes é por natureza e por convenção, coincidentemente, e, portanto, a linguagem é heterogênea, ou por melhor dizer, complexa, como o próprio filósofo, ao dialogar com Crátilo, traz no diálogo platônico: parece, de fato, que os instituidores dos nomes os formaram partindo do pressuposto de que todas as coisas passam e se encontram num fluxo perpétuo (Sócrates, 439c). Por esta assertiva, entendemos que a linguagem se apresenta como um instrumento multifacetado, já que nos dá acesso à realidade, esta que é constituída por movimentos múltiplos e contínuos.

Diante disso, é possível perceber a aporia ${ }^{3}$ presente na obra, em razão do diálogo ser inconclusivo, encontrar-se em constante imprecisão, já que Sócrates revela o caráter inexato das teses apresentadas, encerrando o diálogo sem uma conclusão acerca da discussão posta sobre a origem da aplicação dos nomes às coisas, da linguagem, portanto, enquanto ferramenta que dá acesso à realidade e ao conhecimento. Decerto, é possível afirmar que, devido a isso, o Diálogo Crátilo ainda é foco de grandiosas pesquisas que constantemente surpreendem teóricos e estudiosos que destinam o

3 Conforme Dicionário Filosófico (COMTESPONVILLE, 2003), aporia é uma contradição insolúvel, ou uma dificuldade impossível, para o pensamento. Por exemplo, a questão da origem do ser é uma aporia: porque toda origem supõe o ser, e portanto, não poderia ser explicada. A aporia é uma espécie de enigma, mas considerado de um ponto de vista mais lógico do que mágico ou espiritual. É um problema que renunciamos a resolver, pelo menos provisoriamente, ou um mistério que nos recusamos a adorar. (In: https://sites. google.com/view/sbgdicionariodefilosofia/aporia. Acesso em: 15 nov. 2019). 
olhar sobre as diferentes perceptivas de discussões nele expostas, especialmente a linguagem.

Em suma, o diálogo pode ser compreendido seguindo a lógica de três momentos: i) a posição da linguagem como representação exata das coisas - naturalismo; ii) a posição da linguagem como resultado de uma criação humana convencionalismo; e iii) o confronto e a relação entre as duas posições, através de Sócrates, que apresenta uma discussão em torna da linguagem e do conhecimento.

De modo a elucidar a compreensão a respeito dessas teses, a seção a seguir as explicita, fazendo uso de exemplos ilustrativos.

\section{Os nomes e as coisas: por natureza ou convenção?}

Escrito por Platão, o Crátilo apresenta um diálogo acerca da justeza dos nomes, em relação às coisas, isto é, de que modo uma palavra designa um objeto? Por que a palavra "cadeira", e não outra, designa o objeto "cadeira"? Por que usamos a palavra "banco" para designar uma instituição financeira ou um assento? Conforme apresentado anteriormente, o diálogo platônico discute duas teses que buscam explicar, ou melhor, refletir sobre a aplicação dos nomes em relação às coisas.

Oliveira (2001), ao apresentar uma discussão a respeito do naturalismo e do convencionalismo, aponta o Crátilo de Platão como o escrito mais tardio e significativo da Tradição que traz uma reflexão sobre a linguagem. $O$ autor faz uma releitura da obra, no tocante ao problema da linguagem em relação à realidade, isto é, dos nomes em relação às coisas, postulando que o naturalismo e o convencionalismo consistem em duas posições que entraram em disputa na história da semântica em busca de explicar a origem dos nomes.

Com essas duas posições, Platão defende que há uma certa afinidade natural entre som e significação. As onomatopeias, por exemplo, não se resumem à imitação fonética do som das palavras (toc-toc da porta, por exemplo), estas apresentam a coisa. Sobre isso, Pereira (2008, p. 11) acrescenta que "a linguagem está para a essência das coisas como o som imitador na voz do homem está para o som real que tenta imitar".

Com isso, o filósofo passa a concordar com a tese naturalista, anunciando que as ações se realizam segundo sua própria natureza, não conforme a opinião que dela fižermos (Sócrates, 387a). De modo a exemplificar esta posição de Platão, é possível pensar acerca da essência das coisas, por exemplo: não posso cortar uma madeira com uma tesoura, e sim com um serrote ou um machado. Ou seja, não podemos falar o nome da coisa sem conhecer a realidade da coisa, a sua natureza.

Concomitante a isso, "ser natural significava ter origens em princípios eternos e imutáveis fora do próprio homem, e por isso invioláveis" (DIETZSCH, 2007, p. 47). Em outras palavras, o naturalismo defende a seguinte tese: a palavra é uma representação exata das coisas, isto é, correta e verdadeira, uma vez que não muda, nem tampouco sofre interferência humana.

No entanto, essa tese, por si só, éinconsistente, e Platão complementa seu pensamento defendendo também o convencionalismo, para dizer que na formação das palavras há muita convenção, isto é, a linguagem é determinada por nós em sociedade, resultado de uma criação humana. O filósofo Platão, na pessoa de Sócrates, dialogando com Hermógenes, expressa: O que en digo é que, ao referirse à raça de ouro, não queira dar a entender que ela fosse, de fato, feita de ouro, mas que era boa e nobre. E a prova é que a nós outros dá a denominação de raça de ferro (Sócrates, 398a). Com isso, o filósofo postula que a coisa recebe um nome e o seu significado passa a ser "julgado" conforme o conhecimento da coisa. A esse respeito Dietzsch (2007, p. 47) acrescenta que "por convencional entendia-se o que resultava do 
costume e da tradição, advindos de algum acordo tácito, ou de um contrato social, praticado por membros da comunidade".

No entanto, o diálogo permite que reflitamos acerca da não possibilidade de concebermos a linguagem apenas por convenção, pois "nenhum conhecimento verdadeiro seria possível, já que o Mundo seria apenas um fluxo permanente, onde nenhum objeto estabilizar-se-ia o suficiente para ser conhecido ou mesmo denominado" (PIQUÉ, 1996, p. 175). Isso porque, em outras palavras, cada um de nós conceberia um nome às coisas, conforme percepções individuais de mundo, bem como valores socioculturais, e, com isso, a comunicação, até mesmo entre comunidades de um mesmo país, se tornaria difícil, pois teríamos outros tantos nomes para designar uma mesma coisa.

O diálogo segue, e, com essa reflexão, Platão trata a linguagem como sendo de natureza bíbrida (Crátilo, 408c), o que significa dizer que o homem procura nomear as coisas conforme suas percepções de mundo, considerando também a natureza dessas coisas, o que possibilita uma certa estabilização para designar algo. Ou seja, a linguagem não pode ser explicada nem por natureza, nem por convenção, e sim por ambas, uma vez que, como o próprio diálogo traz, as coisas fluem, movimentam-se, transformam-se, e "julgar" o nome que designa determinada coisa, desconsiderando a existência de outros para a mesma coisa, é incoerente, pois um mesmo objeto (coisa) pode ter mais de um nome a depender da cultura de um povo, haja vista que, por exemplo, em diferentes partes do país usa-se os nomes abóbora e jerimum, mandioca e aipim, para designar um mesmo objeto (coisa).

A respeito dessas duas teses, Piqué (1996, p. 173) exemplifica essa reflexão dizendo que "se uma tesoura corta uma folha de papel, é porque a folha é "cortável", isso faz parte de sua natureza", o que nos leva a compreender que o homem pode cortá-la conforme interesses individuais, crenças e valores socioculturais. Isso refere-se, pois, tanto à natureza quanto à convenção.

Diante das proposições postas, e conforme Oliveira (2001) discute, Platão apresenta um novo problema relativo a toda a discussão, revelando ser "possível, portanto, conhecer as coisas sem os nomes" (OLIVEIRA, 2001, p. 22). Essa é a tese de Platão: a linguagem é secundária em relação à coisa, isto é, os objetos existem independentemente dos nomes que os designam. Sobre isso, o autor esclarece, ainda que, para o filósofo, "a linguagem é reduzida a puro instrumento, e o conhecimento do real se faz independentemente dela" (OLIVEIRA, 2001, p. 22). Em suma, a linguagem é tida como um instrumento posterior à realidade, que tem como função designar as coisas, logo, o mundo, tal como concebemos, é constituído na linguagem.

Considerando a complexidade acerca da linguagem, bem como a impossibilidade de estudála sem considerar a essência filosófica inerente à ela, a seção a seguir apresenta uma (re)discussão teórica a respeito deste instrumento do conhecimento, intencionando expor uma reflexão clara, acentuada e compreensiva quanto ao que abordam os diálogos atuais, a partir da discussão trazida no Crátilo.

\section{(Re)discutindo a linguagem: do Crátilo aos diálogos atuais}

O estudo acerca do ato de nomear e a justeza dos nomes em relação às coisas é uma preocupação antiga dos linguistas e especialmente dos filósofos, que há muito tempo discorrem sobre a referência feita às coisas por meio da linguagem. O Diálogo Crátilo, por exemplo, manuscrito do século IV antes de Cristo, por apresentar uma discussão a respeito da origem dos nomes, comprova esta visão, comumente defendida por vários autores, a exemplo de Teixeira e Soares (2013).

Nessa perspectiva, pensemos, inicialmente, a linguagem no Diálogo Crátilo tida como o 
instrumento que produz o conhecimento, designa as coisas e materializa o real ao homem. Comentando o manuscrito, Santos (2009, p. 739) compreende a linguagem como "fundamento da efetivação de qualquer coisa dentro do real", o que é coerente com o entendimento dos nomes enquanto uma representação dos objetos, das coisas no mundo.

No entanto, essa asserção é um tanto inconsistente, ou relativa, por melhor dizer, uma vez que temos nomes que não podem ser representados pelas coisas. Quando se fala de cores, “verde", "vermelho" e "azul", por exemplo, não conseguimos enxergar um objeto correspondente a esses nomes, mas sim outros nomes que nos remetem a objetos, como os lápis de cores, ou árvore, sangue e céu, respectivamente. O mesmo acontece com as palavras "doce" e "azedo", para as quais não pensamos, de imediato, em um objeto que as represente, e sim em "sorvete" e "limão" como correspondentes a tais.

O Crátilo apresenta essa discussão em vários momentos do texto, a exemplo da seguinte asserção: as coisas têm, por elas mesmas, um ser permanente, que não é relativo a nós nem depende de nós (Crátilo, 386e), que só é inteligível quando se compreende que, para personagem Crátilo, todos os nomes são justos, já que o uso da linguagem permite-nos fazer referência às coisas do mundo. No entanto, para alguns objetos não há uma referência imediata, direta, como os exemplos dados anteriormente ilustram.

A partir disso, entende-se, portanto, que existem determinadas palavras para as quais não há uma representação direta, em se tratando de objeto. Esse entendimento nos leva a conceber que "a linguagem, enquanto instrumento, tem o seu papel no aprimoramento do intelecto e é um meio na busca do conhecimento da essência" (PIQUÉ, 1996, p. 180).

Sobre isso, Oliveira (2001, p. 21), a partir da releitura do Diálogo Crátilo, argumenta:
[...] Crátilo defende a tese de que "quem conhece os nomes conhece as coisas" (435d), de tal modo que o conhecimento dos nomes constitui o princípio da sabedoria. Contudo, existe aqui um grande problema, como Sócrates esclarece: todo sistema de nomes pode tanto ajudar como atrapalhar o conhecimento. Daí a necessidade da crítica da linguagem, pois ela é obra humana e, enquanto tal, sujeita a erro (OLIVEIRA, 2011, p. 21).

Dentro dessa visão, Platão, na pessoa de Sócrates, entende a linguagem como uma criação humana, e em razão disso está sujeita ao erro. No que tange ao uso da linguagem, o ser humano tem duas opções: falar com verdade e falar com falsidade, que consistem em dois tipos de discursos postos no texto platônico: a proposição que se refere às coisas como elas são, é verdadeira, vindo a ser falsa quando indica o que elas não são (Sócrates, 385b). O próprio Sócrates relativiza essa colocação declarando não existir discursos mais verdadeiros ou mais falsos que outros, pois as concepções de verdade e falsidade se diferem a cada pessoa. Pensar dessa forma nos leva questionar a exatidão dos nomes: determinado objeto é realmente designado por tal palavra? Por que esse nome e não outro? Questões como estas são provocadas com a leitura do Diálogo Crátilo.

De modo a atestar a aporia presente na obra, discutida por vários autores, a exemplo de Santos (2010), o discurso do próprio Platão, ao referir-se a Crátilo, é um forte argumento, para quem o modo de alcançar o conbecimento das coisas, ou descobri-las, é questão que talvez. ultrapasse a minha e a tua capacidade (Sócrates, 439b), revelando assim que a busca pela compreensão da teoria do conhecimento linguagem - é complexa e manifesta-se, ao final do diálogo, sem uma resposta conclusiva, sem uma verdade plena.

Por outro lado, é coerente dizer que o diálogo chega a uma rasa conclusão quanto à aplicação dos nomes às coisas, também através de Platão, que declara não ser por meio de seus nomes que devemos procurar conbecer on estudar as coisas, mas, de preferência, por meio delas próprias (Sócrates, 439b), 
uma vez que, segundo a sua tese, objetos existem independentemente dos nomes que os designam, isto é, os nomes são posteriores às coisas, e por isso $\mathrm{o}$ ato de nomear exige conhecer as coisas, dado que não se pode nomear a coisa sem antes conhecê-la.

Ainda a esse respeito, Pique (1996) postula que, no diálogo, embora com uma discussão aporética, Platão considera suficiente constatar que não é por meio dos nomes que devemos procurar conhecer ou entender as coisas, e sim por elas mesmas, já que, como dito anteriormente pelo próprio filósofo, o conhecimento do real precede à linguagem, muito embora o mundo, tal qual concebemos, é constituído pela linguagem.

Concomitante a isso, o texto platônico, encaminhando-se para “o final”, enuncia, na voz da personagem Sócrates, que: partindo do princípio de que tudo passa, e se movimenta, e corre, dissemos que os nomes revelam a essência das coisas (Sócrates, 439c), o que revela que o Crátilo, embora seja um escrito longínquo, é uma discussão atual, já que esse princípio corrobora com a concepção - funcionalista - que temos (ou devemos ter) de língua: mutável, fluída, que segue movimentando-se e transformandose constantemente, conforme necessidade dos falantes. Com efeito, acredita-se que estaria no "final" do Crátilo as suas mais importantes ideias, que culminaram em valiosas discussões acerca da linguagem desde seu escrito até os dias atuais (DIETZSCH, 2007). Daí a importância de elucidar a compreensão a respeito desse manuscrito.

Nessa perspectiva, soma-se, a propósito, nesta discussão, tratar da linguagem, a partir do que apresenta o Crátilo, nos diálogos atuais, especificadamente o ato de referir-se às coisas - estudo da referência. Sobre isso, Mondada e Dubois (2003, p. 18) discorrem que:

A questão de saber como a língua refere o mundo tem sido colocada há muito tempo em diversos quadros conceituais. Se as respostas são diferentes, a maior parte pressupõe ou visa uma relação de correspondência entre as palavras e as coisas, correspondência dada, preexistente e perdida, ou recuperar, encontrar no exercício da atividade científica, por exemplo.

No estudo da referência, as autoras tratam, inicialmente, de uma concepção extramental de designação das coisas, tendo a linguagem o poder de referenciar as palavras às coisas por uma via direta e estável. As autoras (re)atualizam esta visão voltando a atenção não mais para o problema de nomear o mundo, e sim em como as atividades relativas à linguagem estruturam e dão sentido a este. Ou seja, o estudo evolui, deixa-se de questionar, na tentativa de explicar, porque determinada coisa tem dado nome, e, ainda, de conceber a coisa como objeto de mundo, passando a ser vista como objeto de discurso.

A aceitação desse postulado implica rever a relação nome e coisa sob uma outra linha argumentativa: a perspectiva interacionista e discursiva da língua, que considera a instabilidade dos objetos. "Parede", por exemplo, além de designar uma obra que delimita as partes internas e externas de uma construção, pode designar também, metaforicamente falando, uma pessoa que, dispersa, não dá a devida atenção a uma outra em uma conversa, "Parece-me que estou conversando com as paredes", exemplificando. Em outras palavras, estudar a ação de nomear as coisas implica desconsiderar um mundo universal, e, como consequência, considerar as atividades humanas, e de natureza diversa, de um sujeito cultural, histórico e social que, fazendo referências às coisas, constrói versões individuais do mundo (MONDADA; DUBOIS, 2003). Logo, por esta razão, as coisas, numa perspectiva (re)atualizada da linguagem, são concebidas enquanto objetos de discurso.

Acerca dessa linha de compreensão, uma observação merece atenção: um mesmo nome, designando uma mesma coisa, pode apresentar 
sentidos diferentes a depender de fatores sociais, externos à língua, particulares à cada sujeito, portanto. Como "frio", que, embora num mesmo grau de temperatura, pode ter significado diferente em cada localidade, isto é, a concepção de frio para um indivíduo que mora no Nordeste se difere da de um indivíduo que mora na região Sul do Brasil, por exemplo.

Essa (re)atualização dos estudos da linguagem procura entender os sentidos que atribuímos às coisas aos nomearmos como tal. Como dito anteriormente, existem determinadas palavras para as quais não há uma representação imediata, em se tratando de objeto, e as autoras Mondada e Dubois (2003) argumentam que isso se deve pelo fato de a linguagem não representar objetos de mundo, e sim de discurso - estudo da referenciação.

Ainda a esse respeito, Teixeira e Soares (2013, p. 135) complementam essa visão postulando que $\mathrm{o}$ ato de apontar que a linguagem nos faculta deve ser ressignificado, admitindo o sentido de "referirse a uma entidade dinâmica, constantemente (re) construída no discurso, jamais atribuindo-a um correspondente fixo no mundo". Com efeito, a linguagem não consiste em rótulos das coisas mundanas, pelo contrário, é dinâmica, moldada pelo sujeito que faz uso dela, no entanto se trata de um fenômeno de complexa compreensão, como o manuscrito Crátilo problematiza em seu diálogo.

Embora sendo um manuscrito antigo, e tendo, nos dias atuais, sua discussão ressignificada, as ideias apresentadas nele são válidas, por deixarem lacunas que possibilitaram a continuidade e o surgimento dos estudos que atualmente temos, e, por serem complexas, merecem nossa atenção. Com efeito, o diálogo nos apresenta uma discussão acerca do conceito de referência, hoje ampliada nos estudos linguísticos, a exemplo da referenciação.

Por todas essas observações, é coerente a interpretação de que a nomeação das coisas é dada através das relações que temos com o mundo e com a realidade, materializadas ou não textualmente, por meio da linguagem, mas nunca de modo direto, uma vez que o nosso acesso à realidade nunca é direto. Ademais, por entender que nossa relação com a realidade é sempre mediada pela linguagem, postula-se que esta reflete as diversas transformações da nossa essência humana, traduz nossos pensamentos e a nossa realidade, ainda que não eficazmente.

\section{Palavras finais}

Neste artigo, objetivou-se apresentar uma discussãoemtornodalinguagem, especificadamente, no que se refere à aplicação dos nomes em relação às coisas, partindo de uma discussão antiga, de cunho filosófico, trazida por Platão no Diálogo Crátilo. Com isso, mostrou-se o quão complexa é a compreensão acerca da linguagem, especialmente, nos diálogos atuais - estudo da referência - que considera que esta não se desenvolve igualmente em todos os seres humanos. Isso porque, como vimos, a linguagem faz referência às coisas do mundo conforme o sujeito que faz uso enxerga o mundo, de modo particular a cada um.

Mediante discussões postas, é coerente afirmar que o estudo em torno da linguagem é inconclusivo, e o diálogo platônico revela isso, uma vez que não apresenta respostas acerca da aplicação dos nomes às coisas e da linguagem enquanto instrumento do conhecimento, mas sim problemas, suscita novos questionamentos, inquietações e diversas perspectivas de estudos como temos atualmente. No entanto, o manuscrito apresenta uma relevante exposição acerca da teoria do conhecimento - a linguagem, e Pereira (2008) ratifica dizendo que esta discussão permanece insuperada, dado que, desde a publicação do texto, pouco se avançou consideravelmente 
no esclarecimento da linguagem, esta continua complexa, para citar apenas uma razão a respeito dessa visão.

O diálogo Crátilo, ao apresentar uma reflexão em torno da linguagem, conforme posto nas palavras iniciais deste artigo, faz-se necessário considerar que as teorias e pesquisas realizadas encontram-se voltadas para o diálogo platônico, isto é, os problemas em torno da linguagem estão no Crátilo e sempre voltamos para lá, direta ou indiretamente. Com efeito, acham-se que há avanço, que criamos teorias novas, quando estamos, na verdade, rodeando o Diálogo Crátilo, tudo se volta para o Crátilo, os problemas estão lá e voltamos constantemente para lá, o que implica dizer que os problemas em torno da linguagem (já) estão no diálogo platônico (SANTOS, 2013). Não há, portanto, nada de mais grandioso depois da publicação deste manuscrito.

Sendo a linguagem a questão central dos estudos e pesquisas filosóficas da atualidade, e dada a importância do Diálogo Crátilo para os problemas que envolvem a filosofia da linguagem, é pertinente discorrer a respeito da relevância da reflexão trazida nesse texto para os respectivos estudos. Com este artigo, espera-se, portanto, conduzir uma compreensão esclarecedora acerca desse diálogo em torno da linguagem, bem como para os estudos linguísticos de modo a ampliar as concepções quanto ao do uso dos signos na língua, uma vez que, conforme discutido, os problemas em torno da linguagem são, essencialmente, de origem filosófica.

Acredita-se que, dessa forma, entendamos os nomes e as coisas numa relação dinâmica, de construção e reconstrução da realidade que não é universal a todos, pelo contrário, subjetiva a cada um que faz uso da linguagem para representá-la. Por conseguinte, a partir da discussão apresentada, podemos reconhecer e confirmar a pertinência dos esclarecimentos a respeito do Diálogo Crátilo, uma discussão atemporal que trata da problemática língua e realidade, tão instigadora e requerida nos estudos linguísticos e filosóficos.

\section{Referências:}

DIETZSCH, Mary Julia Martins. Crátilo e a origem dos nomes. In: Revista Internacional d'Humanitats 12, CEMOROC-Feusp / Núcleo Humanidades-ESDC / Univ. Autónoma de Barcelona, p. 47-60, 2007. Artigo disponível em: http://www.hottopos.com/rih $12 /$ maryj.pdf. Acesso em: 18 out. 2019.

MONDADA, L.; DUBOIS, D. Construção dos objetos de discurso e categorização: uma abordagem dos processos de referenciação. In: CAVALCAN'TE, M. M.; BIASIRODRIGUES, B.; CIULLA, A. Referenciação. São Paulo: Contexto, 2003, p. 17-52.

OLIVEIRA, Manfredo Araújo de. Platão: discussão entre naturalismo e convencionalismo. In: Reviravolta lingüístico-pragmática na filosofia contemporânea. São Paulo: Loyola, 2001.

PEREIRA, Américo. Da filosofia da linguagem no Crátilo de Platão. Lisboa: Lusofia, 2008.

PIQUÉ, Jorge Fero. Linguagem e realidade: uma análise do Crátilo de Platão. Revista Letras, Curitiba, n 46, 1996. p. 171-182. Artigo disponível em: https://revistas.ufpr.br/letras/article/ viewFile/19050/12355. Acesso em: 07 out. 2019.

PLATÃO. Teeteto - Crátilo. Tradução de Carlos Alberto Nunes. 3. ed. rev. Belém: Editora EDUFPA, 2001.

PRODANOV, Cleber Cristiano; FREITAS, Ernani Cesar de. Metodologia do trabalho científico: métodos e técnicas da pesquisa e do trabalho acadêmico. 2. ed. Novo Hamburgo: Feevale, 2013.

SANTOS, Ivanaldo Oliveira. O logus do personagem Crátilo no diálogo homônimo de Platão. Fragmentos de Cultura: Goiânia, v. 19, n. 9/10, 2009, p. 735-746. Artigo disponível em: http:// 
seer.pucgoias.edu.br/index.php/fragmentos/ article/view/1158/803. Acesso em: 15 out. 2019.

SANTOS, Ivanaldo Oliveira. A aporia no diálogo Crátilo de Platão. Revista Archai: Revista de Estudos sobre as Origens do Pensamento Ocidental, v. 4, 2010, p. 101-106. Artigo disponível em: https://periodicos.unb.br/index.php/archai/ article/view/2277/2024. Acesso em: 22 out. 2019.

SANTOS, Ivanaldo Oliveira. A influência do diálogo Crátilo de Platão na pesquisa em Filosofia da Linguagem Contemporânea. Contexto (Mossoró), v. 14, 2013, p. 213-221.

TEIXEIRA, Elisângela Nogueira; SOARES, Maria Elisa. Movimentação ocular no estudo do processamento da referência. In: CAVALCANTE, M. M.; LIMA, S. M. C. (Orgs.). Referenciação: teoria e prática. São Paulo: Cortez Editora, 2013, p. 133-159.

Submissão: setembro de 2020 .

Aceite: dezembro de 2020. 